\title{
Comparison of growth and toxicity responses between non-toxic and toxic strains of Prorocentrum hoffmannianum
}

\author{
Thomas Chun-Hung Lee*, Ping-Lung Chan*, Steven Jingliang Xu, \\ Fred Wang-Fat Lee ${ }^{* *}$
}

Department of Science, School of Science and Technology, The Open University of Hong Kong, Hong Kong SAR

\begin{abstract}
We aimed to study the growth and toxicity responses of non-toxic (CCMP683) and toxic (CCMP2804) strains of Prorocentrum hoffmannianum under various nitrate and phosphate concentrations. The 2 strains were cultured in L1-Si medium with standard, depleted or 10-fold repleted nitrate or phosphate. CCMP683 cultured in standard L1-Si medium exhibited delayed growth. Nitrate or phosphate depletion decreased the cell density of both strains. Repletion of nitrate slightly increased the cell density of both strains. Repletion of phosphate also slightly increased the cell density of CCMP2804 but surprisingly decreased the cell density of CCMP683. Okadaic acid (OA) and its derivatives were not detected in CCMP683. OA was detected only in CCMP2804. Depletion of nitrate or phosphate increased the cellular concentration of OA, and repletion of nitrate or phosphate had no effect on the cellular concentration of OA. Correlation analysis indicated that the cellular concentration of OA was negatively correlated with cell density. Differences in the growth response to phosphate repletion and in the ability to produce OA suggest that the 2 strains may be good candidates for comparative studies related to phosphate metabolism and OA toxicity.
\end{abstract}

KEY WORDS: Prorocentrum hoffmannianum $\cdot$ Dinoflagellates · Okadaic acid · Diarrhetic shellfish poisoning $\cdot$ DSP $\cdot$ Harmful algae $\cdot$ Nitrate $\cdot$ Phosphate $\cdot$ Cell cycle

\section{INTRODUCTION}

Harmful algal blooms (HABs) have recently become a major global concern, as their incidence has increased dramatically over the last few decades (Van Dolah 2000). It is believed that global warming and increased anthropogenic activities contribute to the increase of HABs (Berdalet et al. 2016). HABs have resulted in not only economic losses but also marine toxin poisoning in humans due to the consumption of toxins accumulated in shellfish. As a result, investigation into the mechanisms of marine toxin production by the causative marine harmful algae species is warranted to mitigate the effects of HABs. Among all the marine toxins produced by harmful microalgae, diarrhetic shellfish poisoning

${ }^{*}$ These co-first authors contributed equally

${ }^{* *}$ Corresponding author: wflee@ouhk.edu.hk
(DSP)-causing toxins, which include okadaic acid (OA) and its derivatives, are less studied due to the less severe acute symptoms induced compared with other toxins such as paralytic shellfish poisoning toxins (Lee et al. 2016). However, recent findings indicated that DSP toxins are implicated in carcinogenesis (Valdiglesias et al. 2013), and it was shown in a number of studies that long-term, low-dose exposure of OA resulted in increased DNA damage in several human and marine cell types (Traoré et al. 2001, Valdiglesias et al. 2011, McCarthy et al. 2014). These findings highlight the importance of investigating DSP toxins and the related harmful algae species to control HABs and the associated adverse health effects due to DSP toxins (Valdiglesias et al. 2013).

() The authors 2020. Open Access under Creative Commons by Attribution Licence. Use, distribution and reproduction are unrestricted. Authors and original publication must be credited. 
Nitrate and phosphate are crucial to the growth of dinoflagellates and the production of DSP toxins (Paerl 2008, Conley et al. 2009). Nitrate is essential to the synthesis of chlorophyll and shellfish toxins (Anderson et al. 1990, Wang \& Hsieh 2002). Phosphate is crucial for supporting the metabolism of an array of biomolecules, thus in turn impacting a vast number of cell functions including bioenergetics, cell signalling and cell growth. Prorocentrum lima is the major producer of DSP toxins and has been investigated intensively (Shumway 1990, Burgess \& Shaw 2001). For example, Vanucci et al. (2010) reported that the growth of $P$. lima was associated with the increase in the concentration of nitrate and phosphate, but the cellular concentrations of OA and dinophysistoxin (DTX)-1 in the stationary phase were negatively associated with the concentrations of nitrate and phosphate. Other Prorocentrum species include $P$. arenarium (Ten-Hage et al. 2000), $P$. faustiae (Morton 1998), P. concavum (Dickey et al. 1990), P. hoffmannianum species complex (Aikman et al. 1993, Morton et al. 1998, Herrera-Sepúlveda et al. 2015), P. levis (Faust et al. 2008), P. maculosum (Zhou \& Fritz 1994) and P. rhathymum (Caillaud et al. 2010). However, these Prorocentrum species differ in the DSP toxins produced. For example, some $P$. lima and $P$. faustiae strains are capable of producing OA and DTX-1 (Lee et al. 1989, Marr et al. 1992, McLachlan et al. 1994, Morton et al. 1998, Vanucci et al. 2010), while $P$. hoffmannianum and $P$. rhathymum only synthesise OA (Aikman et al. 1993, Caillaud et al. 2010). This phenomenon indicates that there are variations in the metabolism of DSP toxin production among these species and that these variations may be the result of the genetic and physiological variations between these species. Also, physiological responses under different growth conditions, especially under various nitrate and phosphate concentrations, remain unclear in many Prorocentrum species. It is expected that the physiological responses, including growth and toxicity, and the underlying molecular mechanisms between different Prorocentrum species are different. Since most DSP toxin producers except $P$. lima have seldom been investigated, it is essential to investigate the physiological responses of other DSP toxin-producing species under nitrate and phosphate stresses to fully understand the biological principles of the growth and DSP toxin production of microalgae.

A previous study (Lee et al. 2012) indicated that $2 P$. hoffmannianum strains (CCMP683 and CCMP2804) were highly similar to each other (internal transcribed spacer and partial large ribosomal subunit sequences of the 2 strains shared $99.7 \%$ ) but differed significantly in their cellular OA content. Immunoassay and ultra-performance liquid chromatography with fluorescence detection (UPLC-FLD) analysis indicated that no OA was detected in CCMP683, whereas CCMP2804 had the highest cellular content of OA among 8 toxic Prorocentrum spp. strains (Lee et al. 2012). In this study, we performed comparative studies by depleting and repleting nitrate and phosphate in the culture medium to determine the differential responses of the 2 strains in growth and DSP toxin production.

\section{MATERIALS AND METHODS}

\subsection{Algal cultures and cultivation conditions}

Two Prorocentrum hoffmannianum strains (CCMP683 and CCMP2804) were purchased from the National Center for Marine Algae and Microbiota. The 2 strains were inoculated in $100 \mathrm{ml} \mathrm{L1-Si} \mathrm{me-}$ dium prepared with 30 ppt autoclaved natural seawater (nitrate concentration: $883 \mu \mathrm{M}$; phosphate concentration: $36.2 \mu \mathrm{M}$.) The cultures were maintained in a growth chamber at $22^{\circ} \mathrm{C}$ under a $12 \mathrm{~h}$ light: $12 \mathrm{~h}$ dark cycle. Light intensity was adjusted to approximately 3000 lux provided by a cool white fluorescent light. For determination of the growth curve, $1 \times 10^{5}$ cells were inoculated in $100 \mathrm{ml} \mathrm{L1-Si} \mathrm{medium} \mathrm{at} \mathrm{a}$ cell density of $1 \times 10^{3}$ cells $\mathrm{ml}^{-1}$. Cell density was determined every 2 to $3 \mathrm{~d}$ for $42 \mathrm{~d}$. The specific growth rate $(\mu)$ for the exponential growth phase of each strain was calculated using the following equation: $\mu=\left(\ln N_{1}-\ln N_{0}\right) /\left(t_{1}-t_{0}\right)$, where $N_{0}$ and $N_{1}$ are the cell density readings at time $t_{0}$ and $t_{1}$. For determining the growth responses of the 2 strains cultured in various nitrate or phosphate concentrations, cells were cultured in L1-Si medium depleted with nitrate or phosphate, except the residual amount of nitrate and phosphate in the natural seawater used for preparing the L1-Si medium, or in L1-Si medium repleted with 10 -fold of nitrate or phosphate (nitrate concentration: $8.83 \mathrm{mM}$; phosphate concentration: $362 \mu \mathrm{M})$. The duration of the experiment and sampling frequency for cell counting were the same as above. The algal cells grown in L1-Si medium were used as a control for comparison. However, changes in the cell density of the 2 strains could not be compared directly using absolute cell number because of the differences in the cell density between the 2 strains when cultured in standard L1-Si medium. Instead, the percentage change in cell density was 
used to compare changes in the growth of the 2 strains.

\subsection{UPLC-FLD analysis of DSP toxins}

We harvested $2 \times 10^{5}$ cells of the 2 strains from all the experimental conditions listed in Section 2.1 on Days 28 and 50. The cells were sonicated in $500 \mu \mathrm{l}$ of $80 \%$ methanol for 2 min twice. Cell extracts were centrifuged and filtered with a $0.2 \mu \mathrm{m}$ filter to remove cell debris. Filtered cell extracts were mixed with $500 \mu \mathrm{l}$ of hexane for toxin extraction. The methanolic layer was collected, air dried and reconstituted in $100 \mu \mathrm{l}$ of $0.1 \%$ pyrenyldiazomethane (w/v in ethyl acetate) at $37^{\circ} \mathrm{C}$ for $2 \mathrm{~h}$ in the dark for derivatisation. Samples were then sonicated for $10 \mathrm{~min}$ and further incubated at $37^{\circ} \mathrm{C}$ for $2 \mathrm{~h}$ in the dark. The solvent in the derivatised samples was evaporated, and the remaining samples were reconstituted in $200 \mu \mathrm{l} 1: 1$ dichloromethane:hexane (v/v) solution followed by cleanup using a Sep-Pak cartridge (500 mg, Waters). Samples were air dried and reconstituted in $500 \mu \mathrm{l}$ $100 \%$ methanol. UPLC-FID analysis was performed with a Waters ACQUITY UPLC H-class system coupled with a fluorescence detector (Waters); $1 \mu \mathrm{l}$ aliquots of the samples were injected into an ACQUITY UPLC HSS T3 column $(2.1 \times 10 \mathrm{~mm}, 1.8 \mu \mathrm{m}$, Waters $)$. The mobile phase consisted of acetonitrile, methanol and water (8:1:1) and flowed isocratically for $0.5 \mathrm{ml}$ $\min ^{-1}$ at $22^{\circ} \mathrm{C}$. The excitation and emission wavelengths were set at 365 and $415 \mathrm{~nm}$, respectively. Putative toxin peaks were identified by comparison with the retention time of the corresponding toxin standards purchased from the Institute for Marine Biosciences, National Research Council Canada. A toxin sample extracted from Alexandrium tamarense (CCMP116) was used as a negative control.

\subsection{Statistical analysis}

Graphing and statistical analysis were performed using Prism 8.0 (GraphPad Software). Multiple $t$-tests were used for comparing the growth of the 2 strains in standard L1-Si medium. One-way ANOVA with Tukey's multiple comparison test was used for determining the effect of nitrate and phosphate depletion or repletion on the cell density of each strain on different days. Two-way ANOVA with Tukey's multiple comparison test was used for determining the effect of nitrate and phosphate depletion or repletion percentage change in cell density and on the changes in
OA production of the 2 strains on different days. Pearson correlation analysis was used to determine the correlation between cell density and the cellular concentration of OA. A p-value of $<0.05$ was considered to be significant.

\section{RESULTS}

\subsection{CCMP683 growth compared with CCMP2804}

Growth of the 2 strains in standard L1-Si medium over $42 \mathrm{~d}$ was monitored by direct counting of the cell number of the 2 strains under a light microscope, and the growth curve of the 2 strains was established (Fig. 1a). The initial growth rate of the 2 strains was similar from Day 0 until Day 6, when they diverged with CCMP2804 exhibiting faster growth. The cell density of CCMP2804 increased from $1.74 \times 10^{3}$ cells $\mathrm{ml}^{-1}$ on Day 6 and reached the log phase on Day 15 with a cell density of $9.53 \times 10^{3}$ cells ml $^{-1}$. CCMP2804 entered the stationary phase on Day 33 with a cell density of $3.79 \times 10^{4}$ cells $\mathrm{ml}^{-1}$. CCMP683 exhibited delayed growth compared with CCMP2804. It exhibited an initial increase in growth rate $2 \mathrm{~d}$ later (Day 8) than CCMP2804 with a cell density of $1.59 \times 10^{3}$ cells $\mathrm{ml}^{-1}$. It reached the log phase on Day 27 with a cell density of $1.00 \times 10^{4}$ cells ml ${ }^{-1}$ and was $12 \mathrm{~d}$ later than CCMP2804. On Day 42, the cell density reached 3.50 $\times 10^{4}$ cells $\mathrm{ml}^{-1}$ and remained the same on Day 46 . The same phenomenon was observed in CCMP2804 $9 \mathrm{~d}$ later than CCMP683. The cell density of CCMP2804 was significantly higher than that of CCMP683 from Day 10 until Day 37, except on Day 35 (Fig. 1a). However, the cell density of the 2 strains in the stationary phase was similar, suggesting that the maximum capacity of the culture medium was reached. Also, there was no significant difference in the fastest growth rate of the 2 strains (Fig. 1b). CCMP2804 exhibited the fastest growth from Days 15 to 33 with a growth rate of $0.07 \mu$. CCMP683 exhibited the fastest growth on Days 27 to 42 with a growth rate of $0.08 \mu$. Our data indicated that CCM683 exhibited delayed growth compared with CCMP2804, although the maximum cell density and the maximum growth rate of the 2 strains in the culture were similar.

\subsection{CCMP683 OA production in standard L1-Si medium}

We further investigated the production of OA and its derivatives, DTX-1 and DTX-2, by the 2 strains. 

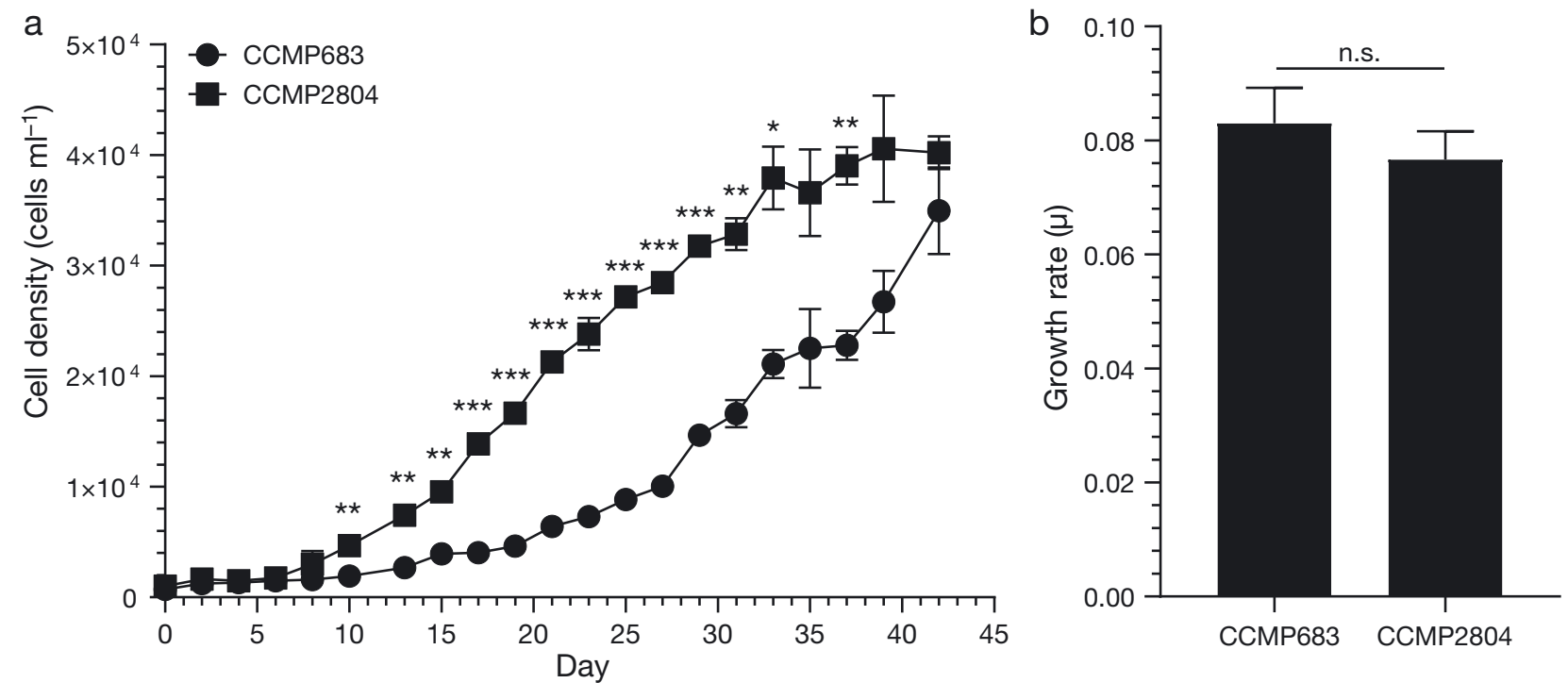

Fig. 1. Growth response of CCMP683 and CCMP2804 in standard L1-Si medium. Cells of the 2 strains were cultured in standard L1-Si medium for $42 \mathrm{~d}$. Cell densities were measured every 2 to $3 \mathrm{~d}$. (a) Growth curve of the 2 strains. (b) Peak growth rate of the 2 strains. All data show mean \pm SD. Three independent experiments were conducted $(n=3)$. ns: no significance. $\mathrm{p}<0.05,{ }^{* *} \mathrm{p}<0.01,{ }^{* * *} \mathrm{p}<0.001$, multiple $t$-tests (a) or $t$-test (b)

Day 28 was chosen for cellular OA measurement because the 2 strains exhibited similar growth rates starting from Day 27 and also showed their maximum growth rates. Day 28 was thus suitable for comparing the toxicity response of the 2 strains. Day 50 was also chosen because it represented the toxicity response in the stationary phase. Fig. 2a shows the representative chromatogram of the UPLC-FID measurement of the 3 toxins. Chromatographic data indicated that OA but not DTX-1 and DTX-2 was detected in CCMP2804. Cells of CCMP2804 had an average of 6.08 and $12.0 \mathrm{pg}$ of OA per cell on Days 28 and 50, respectively (Fig. 2b). Statistical analysis indicated that the cellular concentration of OA on Day 50 was significantly higher than that on Day 28 ( $p<0.001)$. As expected, no toxin was found in the cell extracts of CCMP683 on both days (Fig. 2). This difference prompted us to further investigate the changes in cell density and OA production of the 2 strains cultured in L1-Si medium with various nitrate or phosphate concentrations.

\subsection{Changes in cell density of the 2 strains in various nitrate concentrations}

We investigated changes in the cell density of the 2 strains by depleting and repleting nitrate in L1-Si medium. Comparing the cell density on Day 21 (representing the mid-log phase) and Day 42 (representing the early stationary phase) in different nitrate availabilities, depletion of nitrate in L1-Si medium resulted in a significant reduction in the cell density of both strains (Fig. 3a). On Day 21, nitrate depletion decreased the cell density from $6.41 \times 10^{3}$ cells ml ${ }^{-1}$ in standard L1-Si medium to $1 \times 10^{3}$ cells m${ }^{-1}(\mathrm{p}<0.05)$, equivalent to an $83.9 \%$ decrease in the cell density of CCMP683 (Fig. 3b). On Day 42, nitrate depletion decreased the cell density of CCMP683 from $4.03 \times 10^{4}$ to $1.16 \times 10^{3}$ cells ml $^{-1}$ ( $\mathrm{p}<0.001$ ), equivalent to a $96.7 \%$ decrease in cell density. A similar phenomenon was observed in CCMP2804. On Day 21, nitrate depletion resulted in a $90.4 \%$ reduction in cell density from $2.13 \times 10^{4}$ to $2.02 \times 10^{3}$ cells ml $^{-1}$ (p < 0.001) (Fig. 3a,b). On Day 42, nitrate depletion decreased the cell density by $95.2 \%$ from $4.02 \times 10^{4}$ to $1.91 \times 10^{3}$ cells $\mathrm{ml}^{-1}(\mathrm{p}<0.001)$. The comparison indicated that both strains exhibited about an 80 to $90 \%$ decrease in cell density on Days 21 and 42 when cultured in the nitrate-depleted condition. However, while CCMP2804 exhibited a similar percentage change on both days, CCMP683 exhibited a further decrease in the percentage change on Day $42(p<0.01)$, although both strains attained a similar reduction in the percentage change in cell density on Day 42.

Although changes in the cell density of both strains were similar in response to nitrate depletion in L1-Si medium, the 2 strains responded differently when cultured in nitrate-repleted L1-Si medium. CCMP683 cultured in nitrate-repleted medium exhibited an increase in cell density from $6.41 \times 10^{3}$ to $1.35 \times 10^{4}$ cells $\mathrm{ml}^{-1}(\mathrm{p}<0.05)$ on Day 21 but no significant 
a

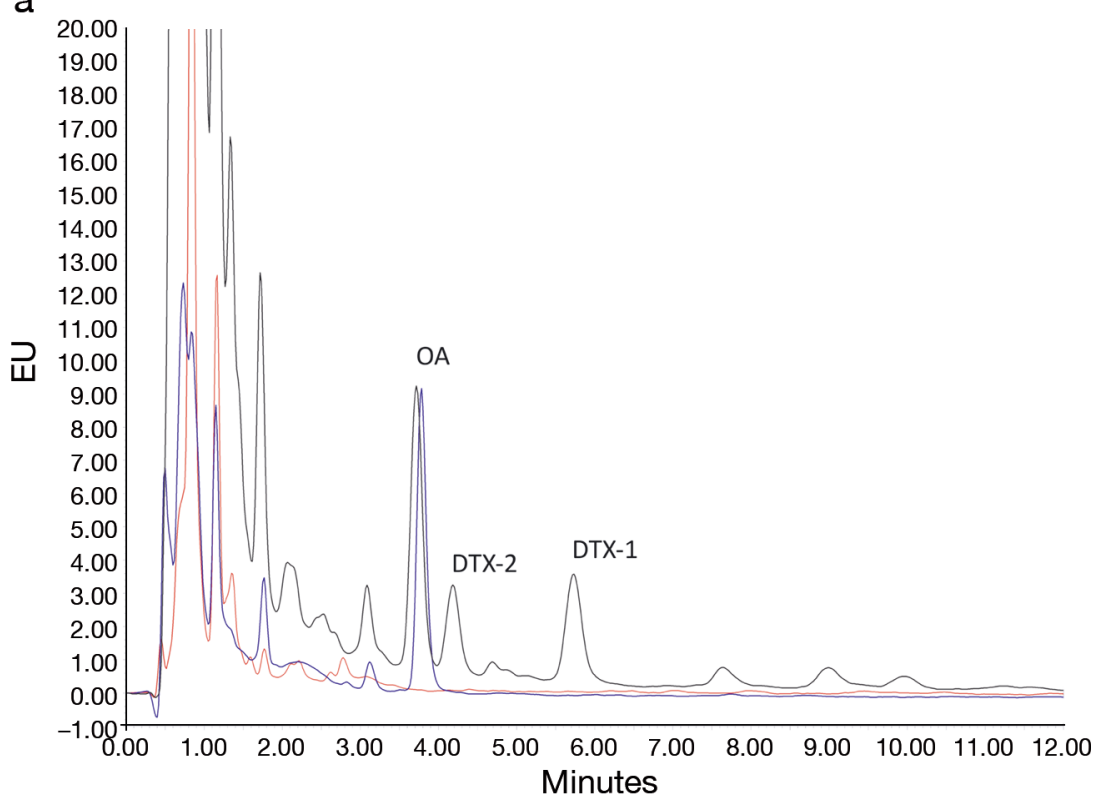

from $4.02 \times 10^{4}$ to $5.31 \times 10^{4}$ cells ml ${ }^{-1}$ $(\mathrm{p}<0.05)$. In terms of the percentage change in cell density, CCMP683 exhibited a $113.7 \%$ increase in cell density, while CCMP2804 exhibited a $6.55 \%$ decrease in cell density on Day 21 ( $\mathrm{p}<0.001$ ) (Fig. 3d). On Day 42, however, the increase in the percentage change in cell density of the 2 strains was not significantly different.

\subsection{Changes in cell density of the 2 strains in various phosphate concentrations}

As phosphate is also crucial to the growth of the 2 strains, changes in the cell density of the 2 strains in L1Si medium depleted $(0 \mu \mathrm{M})$ or re-

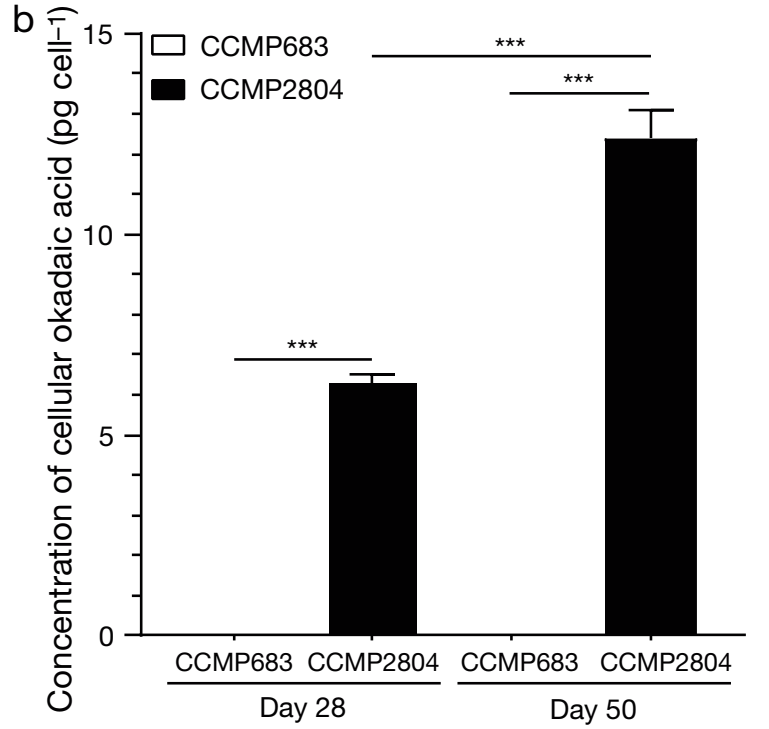

Fig. 2. Measurement of cellular concentration of okadaic acid (OA) and its derivatives in the 2 strains cultured in standard L1-Si medium. (a) Representative chromatogram of ultra-performance liquid chromatography with fluorescence detection analysis of OA and its derivatives (dinophysistoxin [DTX]-1 and DTX-2) in the cell extracts of CCMP683 and CCMP2804. Black line: toxin standard; red line: CCMP683; blue line: CCMP2804. EU: emission unit. (b) Cellular concentration of OA of the cell extracts of CCMP683 and CCMP2804 on Days 28 and 50. Data show mean + SD. Three independent experiments were conducted $(\mathrm{n}=3) .{ }^{* * *} \mathrm{p}<$ $0.001, t$-test

increase on Day $42\left(3.90 \times 10^{4}\right.$ cells ml-1) (Fig. 3c). In contrast, CCMP2804 cultured in nitrate-repleted medium exhibited a slight decrease in cell density from $2.13 \times 10^{4}$ to $1.99 \times 10^{4}$ cells ml ${ }^{-1}$ on Day 21 . However, on Day 41 , nitrate repletion increased the cell density pleted $(362 \mu \mathrm{M})$ with phosphate was also examined. Phosphate depletion decreased the cell density of CCMP683 from $6.41 \times 10^{3}$ to $2.31 \times 10^{3}$ cells ml ${ }^{-1}$ and that of CCMP2804 from $2.13 \times 10^{4}$ to $3.02 \times 10^{3}$ cells $\mathrm{ml}^{-1}$ ( $\mathrm{p}<0.001$ ) on Day 21 (Fig. 4a). These changes in cell density were equivalent to 63.5 and $85.8 \%$ reductions in the cell density of CCMP683 and CCMP2804, respectively ( $p<0.001$ ) (Fig. 4b). A similar reduction in the cell density of both strains was also observed on Day 42. The cell density of CCMP683 and CCMP2804 decreased from $3.50 \times 10^{4}$ to $3.02 \times 10^{3}$ cells ml $^{-1}(\mathrm{p}<0.001)$ and from $4.02 \times 10^{4}$ to $3.23 \times 10^{3}$ cells $\mathrm{ml}^{-1}(\mathrm{p}<0.001)$, respectively (Fig. 4a). However, both CCMP683 and CCMP2804 showed a similar reduction in the percentage change in cell density (91.3 and 91.9\%, respectively) (Fig. 4b). Phosphate repletion led to differential changes in the cell density of the 2 strains with the cell density of CCMP2804 increasing from $2.13 \times 10^{4}$ to $2.29 \times 10^{4}$ cells $\mathrm{ml}^{-1}$ (ns), equivalent to a $7.51 \%$ increase on Day 21 (Fig. 4c,d). This increase was expanded on Day 42 , and the cell density of CCMP2804 increased by $21.9 \%$ from $4.02 \times 10^{4}$ to $4.90 \times 10^{4}$ cells ml ${ }^{-1}$ ( $\mathrm{p}<$ 0.001). Phosphate repletion, however, surprisingly decreased the cell density of CCMP683. On Day 21, the cell density of CCMP683 decreased by $4.92 \%$ from $6.41 \times 10^{3}$ to $6.08 \times 10^{3}$ cells ml $^{-1}$ (ns) (Fig. $4 \mathrm{c}$, d) This decrease was widened to $32.0 \%$ on Day 42 as compared with $4.92 \%$ on Day 21 ( $p<0.05$ ), and the cell density of CCMP683 decreased from $3.50 \times 10^{4}$ to $2.36 \times 10^{4}$ cells ml ${ }^{-1}(\mathrm{p}<0.01)$. Our data showed that the 2 strains exhibited differential changes in cell density in response to phosphate repletion in L1-Si. 

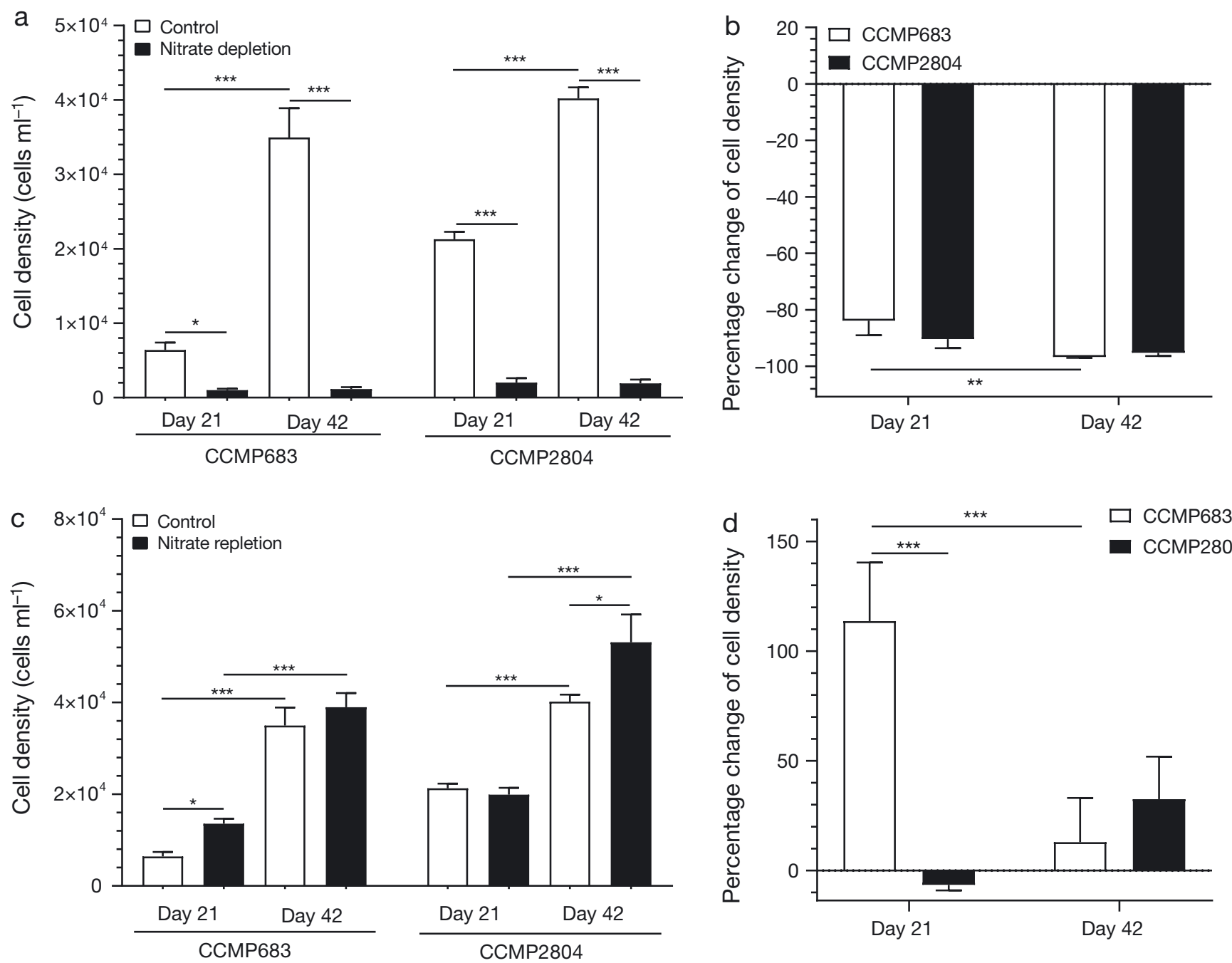

Fig. 3. Effect of nitrate depletion and repletion on cell growth. Cells of the 2 strains were cultured in L1-Si medium: (a,b) depleted in nitrate or $(c, d) 10$-fold repleted with nitrate. Changes in cell density were measured on Days 21 and 42 . The 2 strains were analysed $(\mathrm{a}, \mathrm{c})$ independently in absolute cell number by 1-way ANOVA with Tukey's multiple comparison test or $(b, d)$ collectively in percentage change in cell density by 2-way ANOVA with Tukey's multiple comparison test. All data show mean $+\mathrm{SD}$. Three independent experiments were conducted $(\mathrm{n}=3) .{ }^{*} \mathrm{p}<0.05,{ }^{* *} \mathrm{p}<0.01,{ }^{* * *} \mathrm{p}<0.001$

\subsection{Response of cellular concentration of $\mathrm{OA}$ under various nitrate and phosphate concentrations in L1-Si medium}

The absence of detectable concentrations of cellular OA in CCMP683 in standard L1-Si medium and the differential responses in the cell density of the 2 strains under various growth conditions prompted us to characterise the changes in the cellular concentration of $\mathrm{OA}$ in the 2 strains under the various culture conditions examined in Sections 3.3 and 3.4. The cellular concentration of OA, DTX-1 and DTX-2 in cell extracts was measured on Days 28 and 50. Similar to previously reported results, no DTX-1 and DTX-2 was detected in the cell extracts of both strains in all conditions tested (Fig. 5a). Also, changes in culture conditions did not result in any measurable concentration of OA in CCMP683 (Fig. 5). However, OA was found in CCMP2804 cultured in standard L1-Si medium. The cellular concentrations of OA on Days 28 and 50 were 6.31 and $12.40 \mathrm{pg} \mathrm{cell}^{-1}$, respectively.

However, nitrate depletion increased the cellular concentration of OA in CCMP2804 on both Days 28 and 50 (Fig. 5a). The cellular concentration of OA was increased to $21.38 \mathrm{pg}$ cell $^{-1}$ on Day 28 ( $\left.\mathrm{p}<0.05\right)$. The same trend was also observed on Day 50. The cellular concentration of OA in CCMP2804 increased to $45.38 \mathrm{pg} \mathrm{cell}^{-1}$ and was significantly higher than that of the control $(p<0.05)$. The cellular concentra- 

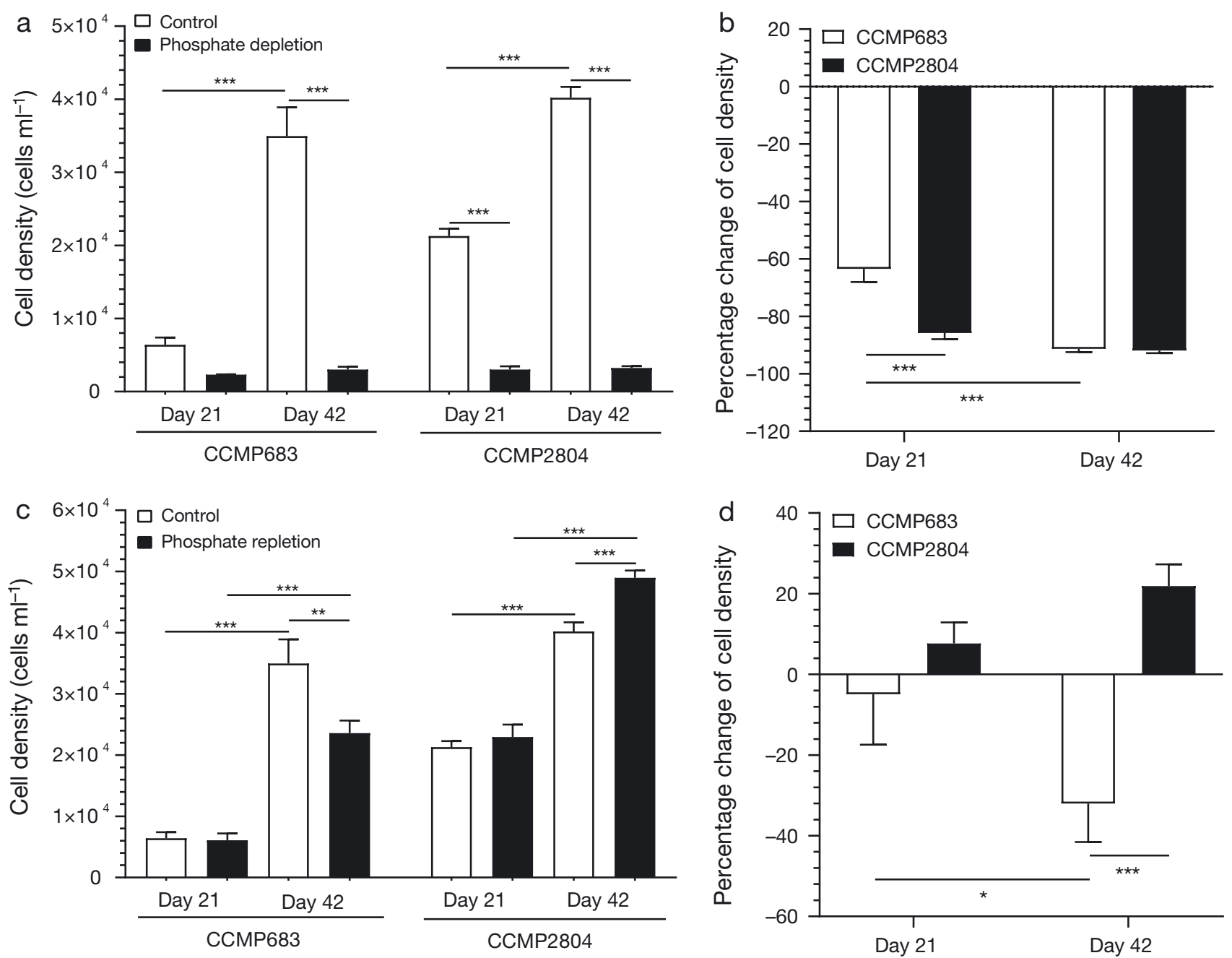

Fig. 4. Effect of phosphate depletion and repletion on cell growth. See Fig. 3 for details

tion of OA on Day 50 was also significantly higher than that on Day 28 ( $p<0.001)$. However, in contrast, repletion of nitrate did not result in any significant change in the cellular concentration of OA (Fig. 5a). The concentration of OA was $16.38 \mathrm{pg} \mathrm{cell}^{-1}$ on Day 50.

A similar phenomenon was also observed when phosphate concentration was varied. Phosphate depletion increased the cellular concentration of OA from 6.31 to $18.86 \mathrm{pg} \mathrm{cell}^{-1}$ on Day 28 (p < 0.05) and from 12.37 to $67.03 \mathrm{pg}$ cell $^{-1}$ on Day 50 ( $\mathrm{p}<$ 0.001) (Fig. 5b). Also, the cellular concentration of OA on Day 50 was significantly higher than that on Day 28 ( $\mathrm{p}<0.001)$. Similar to nitrate repletion, phosphate repletion did not lead to any significant change in the cellular concentration of OA on both Day 28 (12.57 pg cell ${ }^{-1}$ ) and Day 50 (14.74 pg cell $\left.^{-1}\right)$.

\subsection{Correlation of cellular concentration of $\mathrm{OA}$ with cell density}

The drastic increase in the cellular concentration of OA in cells cultured in nitrate- or phosphatedepleted L1-Si medium prompted us to explore the correlation between cell density and the cellular concentration of OA. The cellular concentration of OA in the cells of CCMP2804 cultured in all growth conditions was correlated with their corresponding cell density on Day 28 using Pearson's correlation test. The same analysis was also performed for data obtained on Day 50. Correlation analysis indicated that the cellular concentration of OA was negatively correlated with cell density on Day 28 with a Pearson's correlation coefficient of -0.737 ( $p=0.002$ ) (Fig. 6a). The same phenomenon was observed on Day 50 with a Pearson's correlation coefficient of -0.877 ( $p<0.001$ ) (Fig. 6b). 

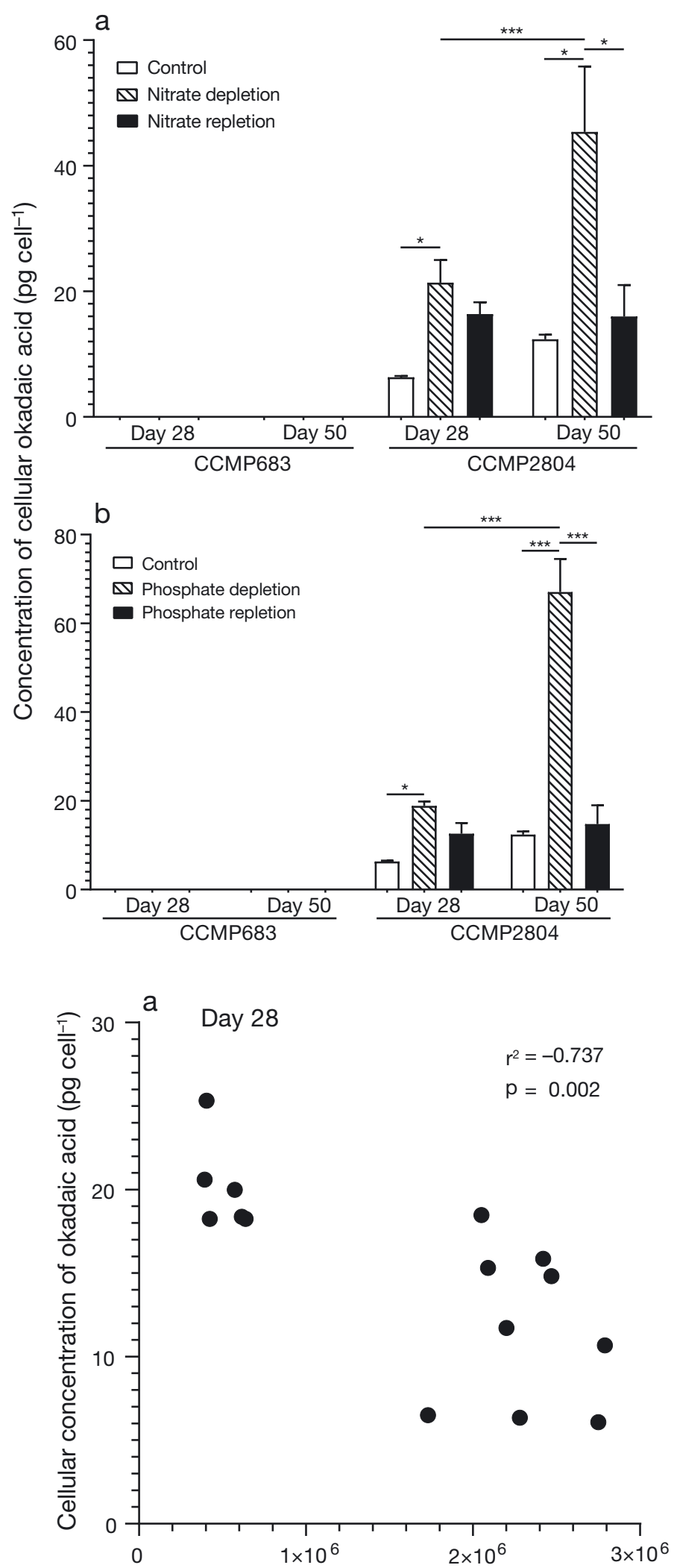

Fig. 5. Effect of depletion and repletion of nitrate or phosphate on cellular concentration of okadaic acid (OA). Cells of the 2 strains were cultured in L1-Si medium with standard, depleted or 10-fold repleted nitrate or phosphate. Cellular concentration of OA was determined using ultraperformance liquid chromatography with fluorescence detection on Days 28 and 50. (a) Effect of nitrate depletion or repletion. (b) Effect of phosphate depletion or repletion. All data show mean + SD. Three independent experiments were conducted $(n=3) .{ }^{*} p<0.05,{ }^{* * *} p<0.001,2$-way ANOVA with Tukey's multiple comparison test

\section{DISCUSSION}

This study compared the growth and toxicity responses of CCMP683 (non-toxic) and CCMP2804 (toxic) under various nitrate and phosphate concentrations. We compared the growth of the 2 strains to determine a suitable timeframe for other studies. Comparison of the growth of CCMP683 and CCMP2804 cultured in standard L1-Si medium over $42 \mathrm{~d}$ revealed that CCMP683 had slower initial growth than CCMP2804 (Fig. 1a). However, the difference in their growth rate on Day 42 was not statistically significant (Fig. 1b). It is also possible for CCMP683 to outgrow CCMP2804, especially since CCMP683 exhibited accelerated growth from Day 37. However, taken together, the similar growth rate of the 2 strains from Days 27 to 33 suggests that comparative studies of the 2 strains can be conducted within this timeframe.

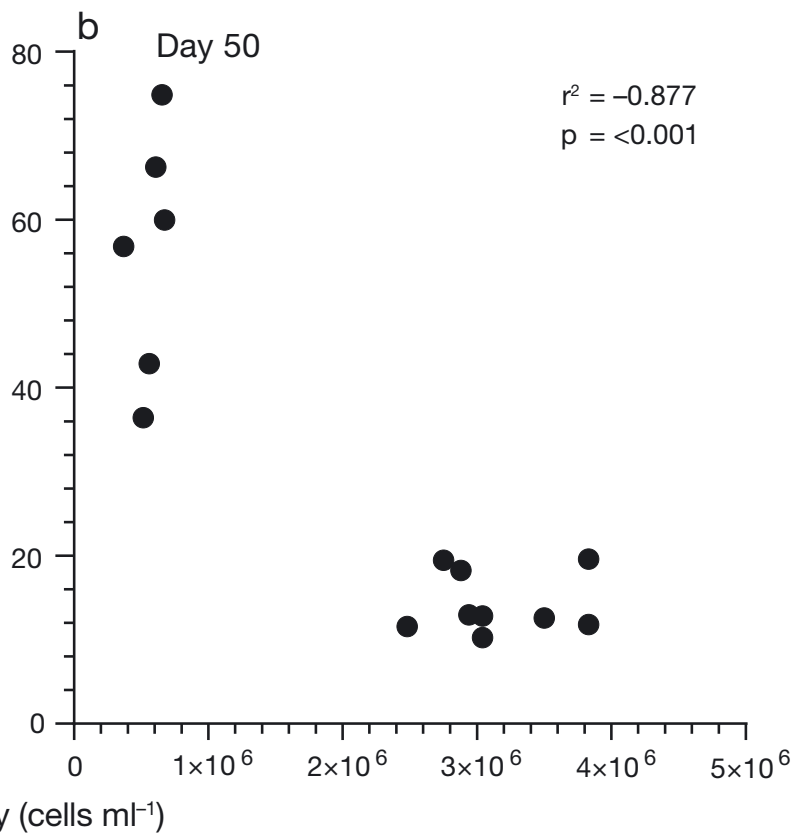

Fig. 6. Cellular concentration of okadaic acid (OA) was negatively correlated with cell density. Cellular concentration of OA in CCMP2804 on (a) Day 28 and (b) Day 50 was correlated with its corresponding cell density using Pearson's correlation test 
We further investigated changes in the cell density of the 2 strains under different culture conditions. It is not surprising that depletion of nitrate or phosphate reduced the cell density of both strains, as nitrate and phosphate are crucial to the growth of microalgae (Figs. 3 \& 4). These findings were consistent with results obtained from other studies on various Prorocentrum species (Morton 1998, Lai et al. 2011, Li et al. 2015b). However, our data suggest that CCMP2804 may be more sensitive to the depletion of nitrate or phosphate than CCMP683 (Figs. 3b \& 4b). This may be due to a lower nitrate or phosphate reserve in the cells of CCMP2804 or an overshooting response of the fast-growing CCMP2804. Further studies are needed to confirm these hypotheses. In addition, contrary to studies by McLachlan et al. (1994) and Morton (1998), nitrate and phosphate repletion only resulted in a modest increase in cell density. It is possible that nitrate and phosphate were not the only limiting factors at the stationary phase; other nutrients such as glucose might also be exhausted while metabolic wastes accumulated.

It is surprising that phosphate repletion reduced the cell density of CCMP683 (Fig. 4). Vanucci et al. (2010) and Sohet et al. (1995) reported that phosphate repletion increased the maximum cell density of $P$. lima and was contradictory to our findings. The reduction in cell density may be due to an increase in cell death, a reduction in cell proliferation or an effect of both (Chan et al. 2013, Zheng et al. 2013). It was reported that excess phosphate inhibited cell growth and decreased cell viability in Protoceratium reticulatum (Gallardo-Rodríguez et al. 2009) and freshwater microalgae (Martínez et al. 1999). It is possible that certain byproducts of phosphate metabolic pathways were lethal to the cells or the surge in phosphate-activated apoptotic kinase. It was demonstrated that an increase in inorganic phosphate concentration resulted in apoptosis and cell cycle arrests through the activation of mitogen-activated protein kinases (Bergwitz \& Jüppner 2011). Also, an excessive amount of phosphate may favour the formation of calcium phosphate crystal in cells, leading to cell death (Ewence et al. 2008). It was reported that calcium phosphate crystals exerted an apoptotic effect in macrophages through the activation of $\mathrm{PKC}$, ERK1/2, and JNK signaling pathways (Hsieh \& Nguyen 2005, Nadra et al. 2005, Sun et al. 2015). Cell density may also be decreased through cell cycle arrest. It was reported that a high concentration of inorganic phosphate led to the cell cycle arrest of human smooth muscle cells (Rahabi-Layachi et al. 2015). However, there is little information on the inhibitory effect of phosphate on the cell growth of dinoflagellates or cyanobacteria, and most studies reported a stimulatory effect of phosphate on cell growth (Li et al. 2015a,b). Our finding highlights that different Prorocentrum species may vary significantly in their metabolisms, and the precise mechanism of the inhibitory effect of high inorganic phosphate concentration on the cell density of CCMP683 remains to be investigated.

Apart from the differences in growth responses, the 2 strains also exhibited different toxicities. While OA could be detected in the cell extracts of CCMP2804 cultured at various conditions, no OA, DTX-1 or DTX-2 could be detected in the cell extracts of CCMP683 at any culture condition examined (Figs. 2b \& 5). Based on our data and the results reported in other studies, it seems that the lack of DSP derivatives is characteristic to Prorocentrum hoffmannianum (Aikman et al. 1993, Morton \& Bomber 1994, Morton et al. 1994). The absence of OA may be attributed to the types of polyketide synthase (PKS) presented in CCMP683 (Macpherson et al. 2003, Snyder et al. 2003) and led to the absence or impairment in the metabolic pathway of OA production. Although Perez et al. (2008) demonstrated that OA could be detected in CCMP683, it should be noted that the detected OA was likely originated from symbiotic bacteria but not from CCMP683 itself. Perez et al. observed that Roseobacter was associated with OA-producing Prorocentrum but not nontoxic Prorocentrum. Subsequent phylogenetic analysis of the PKS gene also revealed that Prorocentrum PKS sequences did not group with those of Cryptosporidium pavum or Karenia brevis, suggesting the detected OA was originated from the symbiotic bacteria (Perez et al. 2008). This observation further strengthens the possibility that CCMP683 is inherently unable to produce OA. It also highlights the need to use axenic culture in microalgae studies to differentiate or exclude factors originated from symbiotic bacteria from the investigated factors.

Our data indicated that depletion of nitrate and phosphate increased the cellular concentration of OA in CCMP2804 (Fig. 5). According to the previous review by Lee et al. (2016) the cellular amount of OA increased when $P$. lima was grown with less than $882 \mu \mathrm{M}$ of nitrate or $30 \mu \mathrm{M}$ of phosphate, but the trend is not in proportion. Our study partially matched with this statement because the proportionality is still unknown. Recent study also investigated the cellular amount of OA in $P$. hoffmanianium under limited nitrate or phosphate at different temperatures. However, the cells seem to be stressed in f/4 
medium with lower amounts of nitrate $(441 \mu \mathrm{M})$ and phosphate $(18.1 \mu \mathrm{M})$ because the maximum cell density in $\mathrm{f} / 4$ medium was only around $2611 \mathrm{cells} \mathrm{ml}^{-1}$, which is approximately $5 \%$ of our study. Therefore, regardless of nitrate and phosphate availability, the cellular amount of OA was higher than that reported by McLachlan et al. (1994), Vanucci et al. (2010) and Accoroni et al. (2018). In comparison with our study, the change in the cellular amount of $\mathrm{OA}$ at $21^{\circ} \mathrm{C}$ under a reduced amount of phosphate is similar but different under a reduced amount of nitrate. The discrepancy is probably due to the increased cellular amount of OA in stressed cells during cultivation in f/4 medium in Accoroni et al.'s (2018) study. No extra amount of OA was produced when the cells were stressed in nitrate-limited medium again.

Correlation analysis suggested that cellular OA concentration was negatively correlated with cell density (Fig. 6). It is unlikely that the reduction in cell density is due to the toxic effect of $\mathrm{OA}$, as it was demonstrated that $P$. lima was immune from the autotoxicity effect of OA (Windust et al. 1996, Sugg \& Van Dolah 1999). Several studies demonstrated that the concentration of nitrate and phosphate was correlated with cell growth but negatively correlated with cell toxicity (Sohet et al. 1995, Li et al. 2009, López-Rosales et al. 2014). Since both nitrate depletion and phosphate depletion increased cellular OA, nitrate and phosphate were unlikely the direct and specific causes of this increase. Instead, the increase in cellular OA is more likely due to the decrease in cell density induced by nitrate or phosphate depletion. Cell cycle progress is closely related to the production of $\mathrm{OA}$ and its derivatives. It was demonstrated in P. lima that the production of DTX-4, OA and DTX-1 were associated with the progress of the G1, S and G2 phases, respectively (Pan et al. 1999). It is thus possible that cells of CCMP2804 entered the G0 phase and were actively producing $\mathrm{OA}$, or that the cell cycle was arrested at the phase which is associated with OA production (Taroncher-Oldenburg et al. 1997). Another possibility is the sharing and competition of the metabolic pathways of cell division and OA production. Wang et al. (2013) demonstrated in $P$. donghaiense that proteins involved in the various crucial biological process were associated with different phases of the cell cycle. It is thus possible that the expression of PKS, which is involved in OA production, may also be associated with a specific phase of the cell cycle. Cell cycle arrest at that phase will, in turn, result in overproduction of OA. Also, since phosphate repletion decreased the cell density of CCMP683, the interaction between phosphate metabolism, cell growth/cell death and OA production should also be investigated. However, to fully answer the relationship between cell death, cell cycle, nitrogen and phosphate metabolism and PKS and OA synthesis, thorough analysis based on flow cytometric techniques, proteomics, genomics and transcriptomics analysis is warranted (Rein \& Snyder 2006).

Acknowledgements. The work described in this paper was partially supported by The Open University of Hong Kong, Research Grant No. 2018/1.9.

\section{LITERATURE CITED}

Accoroni S, Ceci M, Tartaglione L, Romagnoli T and others (2018) Role of temperature and nutrients on the growth and toxin production of Prorocentrum hoffmannianum (Dinophyceae) from the Florida Keys. Harmful Algae 80: 140-148

Aikman KE, Tindall DR, Morton SL (1993) Physiology and potency of the dinoflagellate Prorocentrum hoffmannianum (Faust) during one complete growth cycle. In: Smayda TJ, Shimizu Y (eds) Toxic phytoplankton blooms in the sea. Elsevier, Amsterdam, p 463-468

Anderson DM, Kulis DM, Sullivan JJ, Hall S, Lee C (1990) Dynamics and physiology of saxitoxin production by the dinoflagellates Alexandrium spp. Mar Biol 104:511-524

Berdalet E, Fleming LE, Gowen R, Davidson K and others (2016) Marine harmful algal blooms, human health and wellbeing: challenges and opportunities in the 21st century. J Mar Biol Assoc UK 96:61-91

* Bergwitz C, Jüppner H (2011) Phosphate sensing. Adv Chronic Kidney Dis 18:132-144

* Burgess V, Shaw G (2001) Pectenotoxins - an issue for public health: a review of their comparative toxicology and metabolism. Environ Int 27:275-283

Caillaud A, de la Iglesia P, Campas M, Elandaloussi L and others (2010) Evidence of okadaic acid production in a cultured strain of the marine dinoflagellate Prorocentrum rhathymum from Malaysia. Toxicon 55:633-637

* Chan PL, Zheng J, Liu Y, Lam KT and others (2013) TLR5 signaling enhances the proliferation of human allogeneic CD40-activated B cell induced $\mathrm{CD} 4{ }^{\mathrm{hi}} \mathrm{CD} 25^{+}$regulatory T cells. PLOS ONE 8:e67969

Conley DJ, Paerl HW, Howarth RW, Boesch DF and others (2009) Controlling eutrophication: nitrogen and phosphorus. Science 323:1014-1015

Dickey RW, Bobzin SC, Faulkner DJ, Bencsath FA, Andrzejewski D (1990) Identification of okadaic acid from a Caribbean dinoflagellate, Prorocentrum concavum. Toxicon 28:371-377

Ewence AE, Bootman M, Roderick HL, Skepper JN and others (2008) Calcium phosphate crystals induce cell death in human vascular smooth muscle cells. Circ Res 103: e28-e34

Faust MA, Vandersea MW, Kibler SR, Tester PA, Litaker RW (2008) Prorocentrum levis, a new benthic species (Dinophyceae) from a mangrove island, Twin Cays, Belize. J Phycol 44:232-240

Gallardo-Rodríguez JJ, Miron AS, García MCC, Belarbi EH, Camacho FG, Chisti Y, Grima EM (2009) Macronutrients 
requirements of the dinoflagellate Protoceratium reticulatum. Harmful Algae 8:239-246

Herrera-Sepúlveda A, Medlin LK, Murugan G, SierraBeltrán AP, Cruz-Villacorta AA, Hernández-Saavedra NY (2015) Are Prorocentrum hoffmannianum and Prorocentrum belizeanum (Dinophyceae, Prorocentrales), the same species? An integration of morphological and molecular data. J Phycol 51:173-188

Hsieh MH, Nguyen HT (2005) Molecular mechanism of apoptosis induced by mechanical forces. Int Rev Cytol 245:45-90

Lai J, Yu Z, Song X, Cao X, Han X (2011) Responses of the growth and biochemical composition of Prorocentrum donghaiense to different nitrogen and phosphorus concentrations. J Exp Mar Biol Ecol 405:6-17

Lee JS, Igarashi T, Fraga S, Dahl E, Hovgaard P, Yasumoto T (1989) Determination of diarrhetic shellfish toxins in various dinoflagellate species. J Appl Phycol 1:147-152

Lee TCH, Ho KC, Xu SJL, Lee FWF (2012) Preliminary study of the toxicity of different okadaic acid producing Prorocentrum species. In: Ho KC (ed) New era in HAB research. Prc 5th Int Conf Prev Manage Harmful Algae S China Sea. Hong Kong, p 9

Lee TCH, Fong FL, Ho KC, Lee FW (2016) The mechanism of diarrhetic shellfish poisoning toxin production in Prorocentrum spp.: physiological and molecular perspectives. Toxins (Basel) 8:272

Li LX, Tang JQ, Yang WD, Liu JS, Zhang JJ, Li HY (2009) Studies on toxin production of Prorocentrum lima. Asian $\mathrm{J}$ Ecotoxicol 4:745-750

Li J, Wang Z, Cao X, Wang Z, Zheng Z (2015a) Effect of orthophosphate and bioavailability of dissolved organic phosphorous compounds to typically harmful cyanobacterium Microcystis aeruginosa. Mar Pollut Bull 92:52-58

* Li M, Li L, Shi X, Lin L, Lin S (2015b) Effects of phosphorus deficiency and adenosine 5'-triphosphate (ATP) on growth and cell cycle of the dinoflagellate Prorocentrum donghaiense. Harmful Algae 47:35-41

López-Rosales L, Gallardo-Rodríguez JJ, Sánchez-Mirón A, Cerón-García MC, Belarbi EH, García-Camacho F, Molina-Grima E (2014) Simultaneous effect of temperature and irradiance on growth and okadaic acid production from the marine dinoflagellate Prorocentrum belizeanum. Toxins (Basel) 6:229-253

Macpherson GR, Burton IW, LeBlanc P, Walter JA, Wright JLC (2003) Studies of the biosynthesis of DTX-5a and DTX-5b by the dinoflagellate Prorocentrum maculosum: regiospecificity of the putative Baeyer-Villigerase and insertion of a single amino acid in a polyketide chain. J Org Chem 68:1659-1664

Marr JC, Jackson AE, McLachlan JL (1992) Occurrence of Prorocentrum lima, a DSP toxin-producing species from the Atlantic coast of Canada. J Appl Phycol 4:17-24

* Martínez ME, Jiménez JM, El Yousfi F (1999) Influence of phosphorus concentration and temperature on growth and phosphorus uptake by the microalga Scenedesmus obliquus. Bioresour Technol 67:233-240

* McCarthy M, O'Halloran J, O'Brien NM, van Pelt FFNAM (2014) Does the marine biotoxin okadaic acid cause DNA fragmentation in the blue mussel and the pacific oyster? Mar Environ Res 101:153-160

McLachlan JL, Marr JC, Conlon Keily A, Adamson A (1994) Effects of nitrogen concentration and cold temperature on DSP toxin concentrations in the dinoflagellate Prorocentrum lima (Prorocentrales, Dinophyceae). Nat Toxins 2:263-270
Morton SL (1998) Morphology and toxicology of Prorocentrum faustiae sp. nov., a toxic species of non-planktonic dinoflagellate from Heron Island, Australia. Bot Mar 41: $565-570$

*Morton SL, Bomber JW (1994) Maximizing okadaic acid content from Prorocentrum hoffmannianum Faust. J Appl Phycol 6:41-44

Morton SL, Bomber JW, Tindall PM (1994) Environmental effects on the production of okadaic acid from Prorocentrum hoffmannianum Faust I. temperature, light, and salinity. J Exp Mar Biol Ecol 178:67-77

*Morton SL, Moeller PDR, Young KA, Lanoue B (1998) Okadaic acid production from the marine dinoflagellate Prorocentrum belizeanum Faust isolated from the Belizean coral reef ecosystem. Toxicon 36:201-206

* Nadra I, Mason JC, Philippidis P, Florey O and others (2005) Proinflammatory activation of macrophages by basic calcium phosphate crystals via protein kinase c and map kinase pathways. Circ Res 96:1248-1256

Paerl H (2008) Nutrient and other environmental controls of harmful cyanobacterial blooms along the freshwatermarine continuum. In: Hudnell HK (ed) Cyanobacterial harmful algal blooms: state of the science and research needs. Springer, New York, NY, p 217-237

*Pan Y, Cembella AD, Quilliam MA (1999) Cell cycle and toxin production in the benthic dinoflagellate Prorocentrum lima. Mar Biol 134:541-549

* Perez R, Liu L, Lopez J, An T, Rein KS (2008) Okadaic acid producing species of dinoflagellates share similar polyketide synthase genes. Mar Drugs 6:164-179

* Rahabi-Layachi H, Ourouda R, Boullier A, Massy ZA, Amant C (2015) Distinct effects of inorganic phosphate on cell cycle and apoptosis in human vascular smooth muscle cells. J Cell Physiol 230:347-355

* Rein KS, Snyder RV (2006) The biosynthesis of polyketide metabolites by dinoflagellates. Adv Appl Microbiol 59: 93-125

Shumway SE (1990) A review of the effects of algal blooms on shellfish and aquaculture. J World Aquacult Soc 21: 65-104

Snyder RV, Gibbs PDL, Palacios A, Abiy L, Dickey R, Lopez JV, Rein KS (2003) Polyketide synthase genes from marine dinoflagellates. Mar Biotechnol (NY) 5:1-12

Sohet K, Pereira A, Braekman JC, Houvenaghel G (1995) Growth and toxicity of Prorocentrum lima (Ehrenberg) dodge in different culture media: effect of humic acids and organic phosphorus. In: Lassus P, Arzul G, Erard E, Gentlen P, Marcailiou C (eds) Harmful marine algal blooms. Lavoisier, Paris, p 669-674

* Sugg LM, Van Dolah FM (1999) No evidence for an allelopathic role of okadaic acid among ciguatera-associated dinoflagellates. J Phycol 35:93-103

* Sun Y, Liu WZ, Liu T, Feng X, Yang N, Zhou HF (2015) Signaling pathway of MAPK/ERK in cell proliferation, differentiation, migration, senescence and apoptosis. J Recept Signal Transduct Res 35:600-604

Taroncher-Oldenburg G, Kulis DM, Anderson DM (1997) Toxin variability during the cell cycle of the dinoflagellate Alexandrium fundyense. Limnol Oceanogr 42: 1178-1188

Ten-Hage L, Delaunay N, Pichon V, Couté A, Puiseux-Dao $\mathrm{S}$, Turquet J (2000) Okadaic acid production from the marine benthic dinoflagellate Prorocentrum arenarium Faust (Dinophyceae) isolated from Europa Island coral reef ecosystem (SW Indian Ocean). Toxicon 38:1043-1054 
Traoré A, Baudrimont I, Ambaliou S, Dano SD, Creppy EE (2001) DNA breaks and cell cycle arrest induced by okadaic acid in Caco-2 cells, a human colonic epithelial cell line. Arch Toxicol 75:110-117

Valdiglesias V, Laffon B, Pásaro E, Cemeli E, Anderson D, Méndez J (2011) Induction of oxidative DNA damage by the marine toxin okadaic acid depends on human cell type. Toxicon 57:882-888

Valdiglesias V, Prego-Faraldo M, Pásaro E, Méndez J, Laffon B (2013) Okadaic acid: more than a diarrheic toxin. Mar Drugs 11:4328-4349

Van Dolah FM (2000) Marine algal toxins: origins, health effects, and their increased occurrence. Environ Health Perspect 108:133-141

Vanucci S, Guerrini F, Milandri A, Pistocchi R (2010) Effects of different levels of $\mathrm{N}$ - and P-deficiency on cell yield, okadaic acid, DTX-1, protein and carbohydrate dynamics in the benthic dinoflagellate Prorocentrum lima. Harmful Algae 9:590-599

Editorial responsibility: Wen-Xiong Wang, Kowloon, Hong Kong, SAR
Wang DZ, Hsieh DPH (2002) Effects of nitrate and phosphate on growth and C2 toxin productivity of Alexandrium tamarense CI01 in culture. Mar Pollut Bull 45: 286-289

Wang DZ, Zhang YJ, Zhang SF, Lin L, Hong HS (2013) Quantitative proteomic analysis of cell cycle of the dinoflagellate Prorocentrum donghaiense (Dinophyceae). PLOS ONE 8:e63659

Windust AJ, Wright JLC, McLachlan JL (1996) The effects of the diarrhetic shellfish poisoning toxins, okadaic acid and dinophysistoxin-1, on the growth of microalgae. Mar Biol 126:19-25

Zheng J, Chan PL, Liu Y, Qin G and others (2013) ICOS regulates the generation and function of human CD4 ${ }^{+}$Treg in a CTLA-4 dependent manner. PLOS ONE 8:e82203

Zhou J, Fritz L (1994) Okadaic acid antibody localizes to chloroplasts in the DSP-toxin-producing dinoflagellates Prorocentrum lima and Prorocentrum maculosum. Phycologia 33:455-461

Submitted: July 12, 2019; Accepted: December 20, 2019 Proofs received from author(s): March 4, 2020 